\title{
Nye antikoagulantia - bør vi ha litt kaldt vann i blodet?
}

De nye antikoagulasjonsmidlene, faktor II-hemmeren dabigatran (Pradaxa) og faktor X-hemmerne rivaroksaban (Xarelto) og apiksaban (Eliquis), representerer et nytt behandlingsprinsipp og er etterlengtede alternativer til 50-åringen warfarin, som frem til nå har hatt en enerådende stilling i dette terapisegmentet. Markedsføringen av de nye midlene har - slik vi ser det - vært rettet mot tre antatte fordeler i forhold til warfarin: standardisert dosering (one size fits all), fravær av interaksjonsproblemer og frihet fra INR-monitorering. Er det slik? Og er dette fordelaktig?

Til tross for relativt store studier er ikke alt kjent om nye legemidler på godkjenningstidspunktet. Som regel vet vi likevel litt mer enn det som er viet plass i annonser og markedsføring.

\section{Standardisert dosering}

Dabigatran, rivaroksaban og apiksaban har alle halveringstider som er langt kortere enn warfarin, noe som betyr at en relativt kortvarig forglemmelse - i motsetning til slik det er for warfarin - kan være ensbetydende med terapisvikt. Det er i internasjonale databaser så langt meldt inn foruroligende mange tilfeller av blødninger og slag ved bruk av de nye midlene (1). Studiene som så langt er gjort med de nye midlene, viser at dosevalgene også for disse har elementer av en balanseøvelse der effektoppnåelse må veies opp mot faren for alvorlige bivirkninger (2-4).

\section{Fravær av interaksjoner?}

Alle de tre nye midlene er substrater for cytokrom P(CYP)-450-isoenzymet 3A4 (unntatt dabigatran) og for den cellulære efflukspumpen P-glykoprotein (5). Disse er involvert $\mathrm{i}$ kroppens omsetning av et stort antall legemidler. Dette betyr at både dabigatran, rivaroksaban og apiksaban er sårbare for både potensielt farlige effektøkninger og effektreduksjoner i nærvær av hemmere eller induktorer (5). Det er liten tvil om at warfarin er mer utsatt for interaksjoner enn de nye midlene, men peroral antikoagulasjonsterapi medfører interaksjonsfare - alltid.

\section{Frihet fra INR-monitorering}

Frihet fra INR-monitorering fremstår ved første blikk som fordelaktig både for pasientene (som sparer tid og penger), legene (som sparer tid) og samfunnet (som sparer penger). Det er imidlertid viktig å ha klart for seg at INR-kontroller av warfarinbehandlede pasienter er et velprøvd og effektivt middel for å sikre at den enkelte pasient forskrives optimal dose og tar legemidlet som forskrevet. Dette betyr at fravær av regelmessige kontroller/monitorering kan føre til

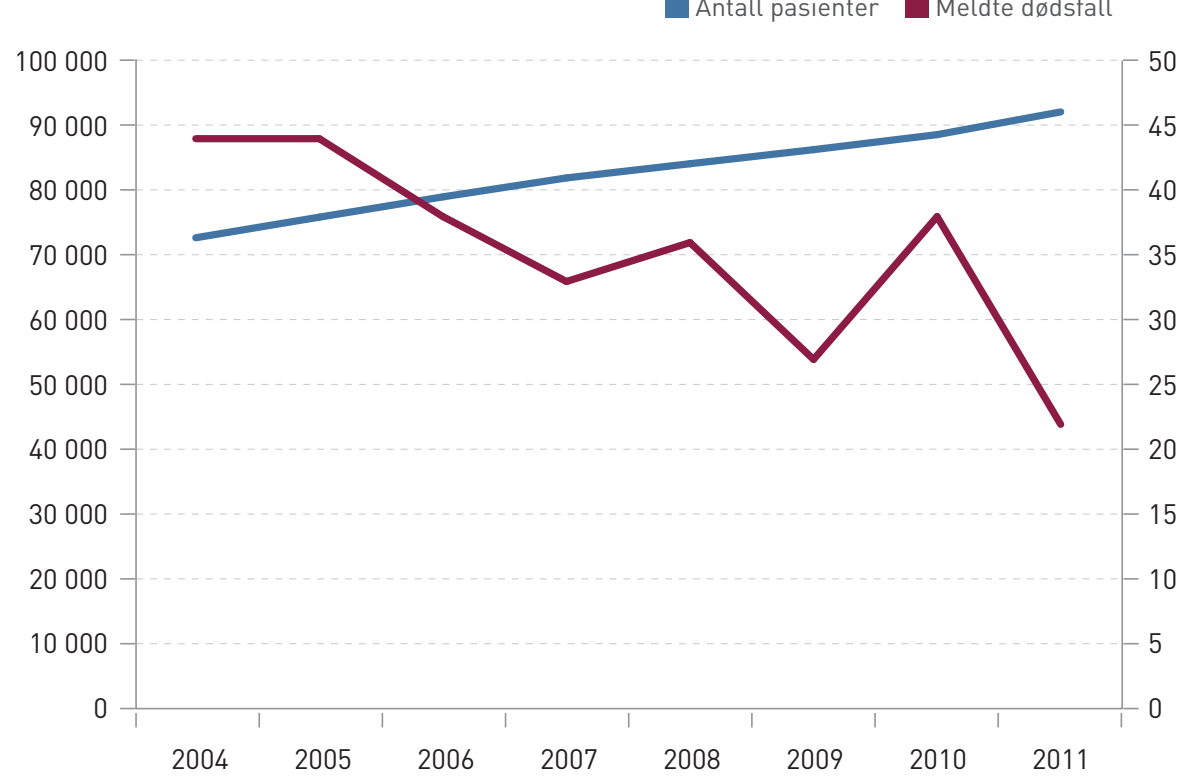

Figur 1 Oversikt over antall brukere av warfarin (blått, venstre ordinat) og antall spontant meldte dødsfall etter warfarinbruk (rødt, høyre ordinat) i tidsrommet 2004-11. Data er fra Reseptregisteret og fra Statens legemiddelverk mangelfull etterlevelse og økt forekomst av alvorlige bivirkninger og terapisvikt.

\section{Litt om studiene}

Studiene som ligger til grunn for de nye antikoagulantias markedsføringstillatelser er mulitinasjonale randomiserte kontrollerte

\section{«Peroral antikoagula- sjonsterapi medfører interaksjonsfare - alltid»}

studier med 14-18 000 pasienter og navn som RE-LY, ROCKET AF og ARISTOTLE (2-4). De har flere fellestrekk som bør mane til forsiktighet når man skal tolke resultatene, fordi de:

- er finansiert og/eller utført av produsentene - er «ikke dårligere enn» (non-inferiority)studier

- inkluderer warfarinpasienter som kanskje ikke er helt representative for norske tilstander.

I løpet av det siste tiåret har antallet brukere av warfarin i Norge økt samtidig med at frekvensen av innmeldte warfarininduserte dødsfall viser en tydelig nedgang (fig 1). De mest sentrale studiene av dabigatran, rivaroksaban og apiksaban (2-4) har så langt vist at de nye midlene ikke er dårligere enn warfarin. Den tiden INR var i målområdet («time in therapeutic range») hos de warfarinbehandlede $\mathrm{i}$ de tre studiene var henholdsvis $64 \%$, $55 \%$ og $62 \%(2-4)$. I en analyse av RE-LY ble det beregnet at norske warfarinpasienter var i ønsket INR-område $70 \%$ av tiden (6), noe som kan tyde på at norske warfarinpasienter har bedre INRkontroll enn gjennomsnittspasientene $i$ hovedstudiene. Videre er pasientene i dabigatran/rivaroksaban/apiksaban-armene trolig blitt vesentlig grundigere fulgt opp og kontrollert enn det som er vanlig for pasienter utenfor studieprotokoller. Begge disse for- 
holdene kan rokke ved» ikke dårligere enn»»påstandene for de nye midlene.

\section{Antidot}

Ingen av de nye antikoagulasjonsmidlene har tilgjengelige antidoter (5), og molekylene er også av en slik størrelse at de neppe kan fjernes ved dialyse. Dette er en betydelig ulempe i forhold til warfarin, der vitamin $\mathrm{K}$ kan reversere en økt blødningsfare. De nye midlenes relativt korte halveringstider gjør at uteglemmelse av bare noen få doser kan gi terapisvikt, men er likevel lang nok til at overdosering kan gi alvorlige blødninger. Med de nye antikoagulasjonsmidlene kan vi heller ikke i motsetning til warfarinterapi - raskt, enkelt og lokalt diagnostisere over- og underbehandling med en blodprøve.

\section{Etterlevelse}

To av de tre nye antikoagulasjonsmidlene skal tas to ganger daglig. Det er $-\mathrm{i}$ andre studier og med andre legemidler - dokumentert at en av de faktorene som gir reduksjon i etterlevelse ved legemiddelterapi nettopp er en økning i antall daglige doseringer og at det største relative frafallet skjer når tablettinntaket økes fra én til to ganger daglig (7). Vi mangler så langt data om etterlevelse ved terapi med de nye antikoagulasjonsmidlene, men fra andre studier med profylaktisk medisinering, som for eksempel med statiner og antihypertensiver, vet vi at halvparten eller flere av pasientene spontant slutter å ta sine medisiner i løpet av relativt kort tid hvis de ikke stimuleres jevnlig (7). Det er foreløpig ikke urimelig å anta at det samme kan skje med pasienter som skal bruke de nye antikoagulasjonsmidlene.

\section{Oppsummering}

De nye antikoagulasjonsmidlene representerer viktige nyvinninger innen sitt terapiområde. Imidlertid krever utstrakt bruk, og spesielt utstrakt substitusjon hos warfarinpasienter, at vi nøye tenker igjennom de problemene også de nye midlene reiser i form av dosering, interaksjoner, monitorering og mulig manglende etterlevelse. I motsatt fall kan en antatt helsegevinst snart bli noe helt annet.

\section{Roar Dyrkorn}

roar.dyrkorn@stolav.no

Pål-Didrik Hoff Roland

Roar Dyrkorn (f. 1954) er spesialist i allmennmedisin og klinisk farmakologi og overlege ved Avdeling for klinisk farmakologi ved St. Olavs hospital, Trondheim.

Forfatter har fylt ut ICMJE-skjemaet og oppgir ingen interessekonflikter.
Pål-Didrik Hoff Roland (f. 1973) er cand.pharm. og ansatt ved RELIS Midt-Norge.

Forfatter har fylt ut ICMJE-skjemaet og oppgir ingen interessekonflikter.

\section{Litteratur}

1. QuarterWatch. Anticoagulants the leading reported drug risk in 2011. Horsham, PA: Institute for Safe Medication Practices, 2012.

2. Connolly SJ, Ezekowitz MD, Yusuf S et al. Dabigatran versus warfarin in patients with atrial fibrillation. N Engl J Med 2009; 361: 1139-51.

3. Patel MR, Mahaffey KW, Garg J et al. Rivaroxaban versus warfarin in nonvalvular atrial fibrillation. N Engl J Med 2011; 365: 883-91.

4. Granger CB, Alexander JH, McMurray JJ et al. Apixaban versus warfarin in patients with atrial fibrillation. N Engl J Med 2011; 365: 981-92.

5. Statens legemiddelverk. Preparatomtaler (SPC) www.legemiddelverket.no/legemiddelsok (22.1. 2013).

6. Wallentin L, Yusuf S, Ezekowitz MD et al. Efficacy and safety of dabigatran compared with warfarin at different levels of international normalised ratio control for stroke prevention in atrial fibrillation: an analysis of the RE-LY trial. Lancet 2010; 376: 975-83.

7. Hov I, Bjartnes M, Slørdal L et al. Tas legemidler som foreskrevet? Tidsskr Nor Legeforen 2012; 132: 418-22.

Mottatt 16.1. 2013 og godkjent 29.1. 2013.

Medisinsk redaktør Siri Lunde.

Publisert først på nett. 